\title{
Transition from Transformational to Traditional Cyclic Recurrence in the Bulgarian Economy
}

\author{
Assoc. Prof. Vera Pirimova, Ph.D. \\ University of National and World Economy, \\ Sofia, Bulgaria, Department of Economics \\ E-mail:v_pirimova@abv.bg
}

\begin{abstract}
The Bulgarian macroeconomic dynamic trajectory in the period $1990-2010$ is taken shape under the determinant action of certain internal and external factors. The most importance among the cumulative internal factors have the processes, related to the market economy transition. They cause fluctuations, what are given expression to specific transformational conditioned instability and cyclic recurrence, prolong until 2008. Under the influence of external factors, reveal from 2009, are taken shape conditions and began transition to the regularities of the traditional cyclic recurrence. Leading importance in this attitude has the profound country participation in the European integration and in the globalization, the increasing degree of the trade and finance openness of the Bulgarian economy. The accessibility and the channels for transfer of cyclical impulses from external sources are increased, but also opportunities and tendencies for raising the degree of the Bulgarian economy cyclical resistibility are built up.
\end{abstract}

Key words: macroeconomic dynamic, transformational cycle, traditional cyclic recurrence, trade and finance openness.

JEL: E01, E32, F43.

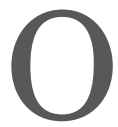
ver the last more than twenty years the development of the Bulgarian economy is related to the implementation of market reforms and transformations. A combination of inside conjuncture factors of temporary (transitional) and in parallel a fundamental character generated by the market restructuring has a profound impact on the entire national economic system. The changing intensity and degree of realization of the underlying institutional and legislative reforms, the transformation of property through privatization, restitution and development of new private businesses, the liberalization of prices and trade, affect the trajectory of macroeconomic dynamics in Bulgaria. In general, they cause a specific transforming conditional instability and a cyclic recurrence.

At the end of the first decade of the 21st century has been made a solid progress in the processes of the market transition, in the stages of gradually building of a new institutional, sectors and industries structure of GDP. In these conditions the country faces a new challenge - the impact of the global financial crisis. Mostly under the influence of external factors it is induced a short-term (one year) decline in the total output, but in individual sectors and industries the crisis intention has been more profound and it still remains unsurmounted.

The specific cyclic resistance of the Bulgarian economy could be revealed on the basis of peculiarities in appearance and timing of 
transformational decline and cycle, their overcoming and the formation of conditions for return of the periodic regularities of the cyclical development. The transition from transformational to traditional cyclic recurrence is largely a projection of the increasing through the years of the market transition parameters of the trade and financial openness of the Bulgarian economy.

\section{Specificity of the Transformational Decrease and Cycle}

$\mathrm{I}_{\mathrm{a}}^{\mathrm{n}}$ the process of market transformation are implemented complex operations and cardinal reorganizations leading to fundamental changes in the type of the economic (and political) system. They create conditions for turmoil and general destabilization of the economy as well as further more vulnerability to adverse external influences. Reforms run with a varying intensity, defining differentiation potential for rising and alternation of temporary, transient and perishable, including episodic, deep declines and high revivals. Macroeconomic fluctuations are sharp and faster, because of the huge, extraordinary and temporary (transitional) nature of the factors that impulse them.

In some countries the induced by the transformation ups and downs are deployed in different ranges - with lesser or greater duration and amplitude of the deviations in the GDP. Depending on the stage reached in bringing them to the market principles of functioning the individual sectors and industries may be affected at different times and in particular extent by the recession impulses of transition.
That's why it is possible to appear some labile structural disproportional events - a transient decrease in some sectors and industries and at the same time an explosive growth in other sectors and industries.

In all cases, the transformation fluctuations, however, have no cyclical basis, nature and periodicity, they don't repeat and appear at regular time intervals. The unprecedented, untypical and transient nature of the causes they have risen, forms their special (non-cyclical) nature, extends their total duration, complicates the outcome of them and the permanent reversal of the macroeconomic dynamics. ${ }^{1}$

The transformational declines or "crises" of the transition are very different from the traditional economic and financial crises and from the main characteristics of the cyclical development. This is emphasized in a set of studies on the issues and peculiarities of the market transition. Thus, according to $\mathrm{Tr}$. Spassov the transformational decrease "couldn't be explained and fit into the concept of the cyclical development. It is because the transformational decrease appears not as one of the phases of the economic cycle, but as an act of profound and structural crisis". ${ }^{2}$ In addition, it should also be borne in mind that the crisis of transition is relatively longer, it has more complex, irregular, heterogeneous internal structure (compared to the classical cyclical crisis).

In most cases, the transformational decline is not a one-way or single phenomenon - consistent reduction of the total output (which is inherent in the descending phase of the traditional economic cycle), after which the economy enters a state of sustained, long-term economic growth. It may cover one or more irregular, non-periodic

\footnotetext{
1 In relation to that Tr. Spassov summarizes: "Transformational decline covers some specific processes of limitation of the total output volume, intensification of the inflation processes and unemployment that are caused by the specific process of changes in the type of economic system". (See CnacoB, Тр., Пазарна трансформация и kонkурентоспособност на иkоноmukume B npexog, УИ „CmonaнсmBo”, C., 2006, с. 77.)

2 Ibid, p. 76.
} 
conjuncture fluctuations determining general for the whole period (long-term) downtrend in the economy. In the conditions of a serious, profound instability, in the trajectory of economic development can appear a series of short and frequent, sometimes one or two years, consecutive periods of growth and decline. They form the internal structure of the transformational crisis, as they show that the crisis situation is not resolved and that the action of factors causing stress and depressing influence on macroeconomic dynamics still works. They keep the total output under its pre-crisis level.

Therefore the unprecedented and non-cyclical nature of the transformational decrease is related with the fact that "achieving a temporary stabilization or episodic growth does not revoke the state of the crisis of transition. "3 Bringing the economy out of the crisis of transition ends with the achievement of more stable macroeconomic and financial stabilization. As a result of the gradual recovery and stabilization of the long-term sources of growth it is possible to be exceeded the precrisis level of GDP, to be normalized the level and dynamics of inflation, unemployment, investments, etc. By that all are formed some prerequisites for initiating the ascending (recovery) phase of the transformational cycle.

During the ascending phase the total output could increase with higher speed (compared to the classical revival). The possibilities for that are provided by the established during the process of transition new, more modern basis, subjects and institutions of the market economic system, and also by the established low output (pre-revival) level of GDP. After a definite period the economic growth rates are kept at a moderate level, as a result of achieving a lasting overwhelm of the transition instability. This sets up the beginning of the impact of regularities of the traditional cyclic development in the economy.

In the disruptive, heterogeneous period of the decline and the subsequent accelerated increasing of the total output are comprised the most essential characteristics of the transformational cycle accompanying the process of the market transition.

In their traditional appearance the separate cyclical fluctuations have common features, but also some certain specifics. It is also true about the transformation cycles, but in opposite interrelation - are found less common features, the peculiarity and uniqueness prevail. General (for all the countries in transition to market economies) are mostly the obligatory appearance and the inevitability of one or more declines, the unified internal basis for their appearance - the processes of market transformation. By the different models and methods for implementation of the market transition and the accompanying processes of transformation, in combination with the other national conditions, the course of transformational declines and cycles is specific, not of one type for all the countries. At the same time by more detailed analysis of the transformational cycle it is established that it has many differences with the periodic economic cycles, but it also includes a set of more specific prerequisites and characteristics of the traditional volatility of the macroeconomic activity. ${ }^{4}$

\footnotetext{
3 Seе СтефаноВ Аим., Българсkияm моgел на прехоgа, В: Проблеми на ukономиkume B npexog, С., uзgam. „Параguгма”, 2000, c. 252.

${ }_{4}^{4}$ Along with the transformational crises are also distinguished some other types of noncyclical crises. L.Grynin and A. Korotaev examine as more specific a wider range of crises of noncyclical type. According to their conceptions the noncyclical crises do not cover the whole national economy but some fields - as finance, trade, stock exchanges and many others. (B*). Грuнuн ^., А. КоротаеВ, Глобальный kрuзис В pempocnekmuße. Краmkая история поgьемоВ и кризисоВ, изgаm. "Книжный gом "АИБРОКОМ", М., 2009, с. 35 и с. 42) In this sense the transformational decline, growth and cycle have certain uniqueness - they are also noncyclical, non-periodical but they have common but not limited and specific character. As a rule they concern the whole economic system although they spread in the separate fields and industries to different extents.
} 


\section{Peculiarities in the Appearance and Transformational Cycle Phases in the Bulgarian Economy}

$\mathrm{T}$ he specification of the trajectory of growth in Bulgaria during the period 1990-2010 is intermediated by the data for the level and dynamics of the created real GDP (see Table 1). The relative change in the total output is presented in two ways - through the chain rates (compared to each previous year) and the basic rates (compared to 1989 - the first year of the market transition). It allows to be identified more clearly the timing and characteristics of several stages and sub-periods in the specific development of the transformational cycle and the implementation of economic transition in Bulgaria:

The first stage is from 1990 to the end of 1997, when the economic transformations are started and the higher intensity has prevailed, but at a certain spontaneity and chaos in the implementation of the market reforms. This has caused a period of unprecedented, profound and long (eight years) transformational economic decline. It is characterized by heterogeneous internal structure - the absolute volume of GDP produced does not goes down continuously, but shows fluctuations, it changes iteratively and unevenly. Based on the change of the reported negative and positive chain rates of alteration of GDP during this period it is formed a heterogeneous, non-uniform order in which can be identified three sub-periods:

* The first sub-period is formed in the range between 1990 and the end of 1993, namely it covers the first four consecutive years of the market transition. For all these years, the real GDP has decreased consistently. It is accumulated a huge neglect in the volume of the output, amounting to a total of $26.3 \%$ compared to its pre-crisis level in 1989. As a result of the undertaken first steps of reforms and economic liberalization it is accelerated significantly the rate of inflation, it is increased dramatically the level of unemployment, and the real incomes and aggregate consumption are reduced. The turmoil and the decline in the total output are characterized by gradual reduction of the strength and profundity - the values of negative growth rates considered in the module decrease. This creates some conjuncture prerequisites, conditions and expectations for mastery of the transition crisis.

* The second sub-period is shorter and it consists of two years - 1994 and 1995. During these years, it is achieved a non-persistent economic recovery, led to a relatively small increase in the real GDP of $4.7 \%$ overall. Both positive increases in GDP are mainly formed under the influence of the higher stage reached in the realization of some market reforms in some areas and fields and the suspension or objective delay of the market reforms in other areas and fields. Especially important are the first and more tangible effects on the total output achieved as a result from the rapid expansion of the new private sector and the reduction of the public sector in the economy. The positive rates of GDP growth have mainly internal conjuncture preconditions complicated by the impact of adverse external factors. For these reasons, the real increases could not persist and continue, it turns out that the growth is unstable, the economic and social intensions remain and it does not form a tendency of long-term overwhelming the macroeconomic destabilization.

* The third sub-period also consists of two years and it is differentiated during 1996-1997. Over these years the crisis has resumed again with much greater force striking both the production and the financial system and has induced their most profound frustration. It is realized a substantial reduction of the total output and as a result the real GDP has decreased with almost 
Table 1. Rates of Changes and Real GDP in Bulgaria (1990-2010) *

\begin{tabular}{|c|c|c|c|}
\hline $\begin{array}{l}\text { Indicators } \\
\text { Year }\end{array}$ & $\begin{array}{c}\text { Rate of GDP } \\
\text { (prev. year = 100) } \\
\text { (percentages) }\end{array}$ & $\begin{array}{c}\text { Rate of GDP } \\
(1989=100) \\
\text { (percentages) }\end{array}$ & $\begin{array}{c}\text { Real GDP } \\
\text { (basic year 1989) } \\
\text { (millions of BGN) }\end{array}$ \\
\hline 1989 & - & - & 39579 \\
\hline 1990 & -9.1 & -9.1 & 35977 \\
\hline 1991 & -8.4 & -16.8 & 32955 \\
\hline 1992 & -7.3 & -22.8 & 30550 \\
\hline 1993 & -1.5 & -24.0 & 30092 \\
\hline 1994 & +1.8 & -22.6 & 30634 \\
\hline 1995 & +2.9 & -20.4 & 31522 \\
\hline 1996 & -9.0 & -27.5 & 28685 \\
\hline 1997 & -5.6 & -31.6 & 27079 \\
\hline 1998 & 4.9 & -28.2 & 28406 \\
\hline 1999 & 2.3 & -26.6 & 29059 \\
\hline 2000 & 5.7 & -22.4 & 30715 \\
\hline 2001 & 4.2 & -19.1 & 32005 \\
\hline 2002 & 4.7 & -15.3 & 33509 \\
\hline 2003 & 5.5 & -10.7 & 35352 \\
\hline 2004 & 6.7 & -4.7 & 37721 \\
\hline 2005 & 6.4 & 1.4 & 40135 \\
\hline 2006 & 6.5 & 8.0 & 42744 \\
\hline 2007 & 6.4 & 14.9 & 45480 \\
\hline 2008 & 6.2 & 22.0 & 48300 \\
\hline 2009 & -4.9 & 16.1 & 45933 \\
\hline 2010 & 0.2 & 16.3 & 46025 \\
\hline
\end{tabular}

*Source: Presented or calculated by the author according to the World Bank databases (till 2008) and EUROSTAT databases (for 2009 and 2010). See: http://data.worldbank.org/indicator/NY.GDP.MKTP.KD.ZG/ countries,

http: $/ /$ epp.eurostat.ec.europa.eu $/$ tgm $/$ table.do?tab $=$ table\&init $=1 \&$ language $=$ en\&pcode $=$ tsieb020\&plugin $=1$

$15 \%$ for two years, a hyperinflation of over 1000 percent has developed as well as a high unemployment. Problems are further aggravated under the influence of a new phase of accelerating the privatization process in the middle of the 90 s and under the impact of a dramatic fiscal restrictions and destabilization of the financial sector. In these conditions, the real incomes of population, the consumer spendings and some other indicators related to welfare have reached their critically low levels. In relation to bringing out of state of severe economic, financial and social crisis in the middle of 1997 the country has introduced the requirements of the Currency Board. They set up the beginning of a gradual economic and financial stabilization which is a condition to be formed more reliable and more sustainable prerequisites and expectations for increasing the rates of economic growth and prosperity. 
By the dynamic characteristics of the first stage and its three identified sub-periods it is drawn the conclusion that throughout the period 1990 - 1997 Bulgaria has been in serious economic difficulties, the implementation of the market transformations has been uneven and with varying intensity and degree of impact on the macroeconomy, the economic destabilization induced by the market transition has remained unsurmounted.

The second stage is the longest - it ranges from 1998 to 2008. It is characterized by a complete mastery of internal and conjuncture induced economic concussions and fluctuations as well as the trends of frequent changes of negative and positive increases in GDP. This is the period of ascending (recovery) phase of the transformational cycle, which Bulgaria entered after the end of the transformational decline in 1997. It is achieved a relative financial and macroeconomic stabilization that allows to be realized an economic growth with relatively high and similar rates within the range of eleven consecutive years. Gradually, it becomes possible the neglect accumulated in the previous crisis years to be neutralized. On the basis of the underlying rates of change in GDP it is found that by 2005 Bulgaria has been able to anticipate and exceed the level of the total output by $1.4 \%$ compared to the pre-crisis $1989 .{ }^{5}$

The continuing economic growth during that second stage is mainly ensured by the increasing investment, particularly in the private sector, the real incomes, the private consumption and the export value. A stimulating impact on the macroeconomic activity has stabilized and moderate inflation rates and the fixed currency exchange rate. They contribute to the formation of optimistic expectations of the economic subjects and it set up a trend of gradual increase of deposits and the use of consumer and business loans. By the high share of private sector, which have already generated more than three quarters of the Bulgarian Gross Value Added, represented in all economic sectors and industries, have been outlined some prospective branch sources of growth.

In all branches where the private sector has become predominant are reported higher physical volume indexes of Bulgarian Gross Value Added that considerably exceeds the index of Gross Value Added in the economy as a whole. The realized by the companies stable and higher revenues and profits and the revival of domestic demand allow the private entrepreneurship to focus on more innovative investments and to orient to some information technology sectors. The improved macroeconomic environment become attractive not only for national but also for foreign investors - in 2007 has been achieved the highest volume of implemented foreign direct investments in the country.

In the extended conditions of competition Bulgarian companies begin to rely on higher-quality products with advanced features that enhance the competitiveness of the local business structures and the economy as well as the export opportunities. The limited size of the public sector and objectively decreasing intensity of privatization ignore some of the most powerful depressing the growth factors in the previous period. After the sale or liquidation of a number of large public companies with difficulties in functioning and the reorganization of the activities of the other public sector companies are

\footnotetext{
5 In some other researches the revival of the pre-crisis level in GDP in Bulgaria is concerned to 2006 or 2004 when it is expressed in US dollars. (See for example, CmameB Cm., Реалната ukономuka и банkоßаmа система на България: емпиричен анализ 1991-2006 г., Научни mpygoßе на УНСС, m. 2, 2009, с. 126) Differences come from the application of another basic year for comparisons. Important are also some fluctuations in statistical databases about the level and dynamics in GDP in some years of the period 1990-2010 according to publications of the National Statistical Institute, the World Bank and EUROSTAT.
} 
reduced the economic and financial losses and costs have fallen from the state budget. In this advanced stage of market transformations are created conditions for further increasing of the investment activity and the export, employment, incomes and domestic demand and for the realization of sustained and rapid growth of the Bulgarian economy.

Under a decisive impact of domestic conditions, the inertia triggered by the success of transformational reorganizing, the established market functioning economic system that is already more competitive and more efficient, the realization of positive increases in GDP with high rates has been in progress to 2008 .

The third stage has begun in 2009. The most typical of its kind has been the setting up of original beginning for the objective laws of traditional cyclical development in the Bulgarian economy. In 2009 the economy of Bulgaria is affected (for the first time after almost twenty years of the market transition) by a short periodic economic crisis. The impulses and reasons for the reported decline in the total output are mainly external, not internal - it is a reflection of the global financial and economic crisis that has begun in USA. At the same time the actual achieved macroeconomic stabilization, the compact resistance of the established market structures and the expressive sources of growth do not allow the decline to become more profound and grow in a recession. They form the opportunities for a quick deal with the recessionary pressure and for a restoration of the positive growth in GDP ever since $2010 .^{6}$
Essential to the final overcoming of the economic turmoil caused by the realization of transformational reforms is the profound participation of the country in the processes of European integration and globalization. They are reflected in the closer commitment of Bulgarian total output and foreign trade with the conjuncture of the regional EU internal market, the increasing of the openness extent of the Bulgarian economy and the inflows of the foreign direct investments. All this have positive effects on the growth, but increases the extent of susceptibility of Bulgarian economy to external influences. On the other hand, their power of influence is limited, however. In this respect the most important role has the improved cyclical stability of the united economy of the European Union, part of which is also Bulgaria, the involvement and commitment of the country in realization of more effective economic policies coordinated at regional (European) level.

The macroeconomic dynamics of Bulgaria and EU (presented in Figure 1.) allows to be emphasized some significant summarizing differences between the period before and after 1997-98, to be derived differentiations that could be reorganized into similarities with the dynamics of the European Union economy.

Over the first eight years of the market transition have dominated the abrupt changes of declines and increases in the real GDP, while over the whole period after 1997 (to the impact of the global crisis in 2009) the total output has developed with stable and high rates, with minor fluctuations of their positive value. This is the basis for the conclusion that after overcoming the re-

\footnotetext{
6 In many researches are presented details and are systemized more concrete prerequisites about the specific extent of spreading, profundity and duration of the global crisis impact on Bulgarian economy. In this relation, for example, Ivan Angelov summarizes: "As a small country with weakly developed economy that has strong sociability, Bulgaria could not stay isolated from the global financial and economic crisis. The impact of the crisis on the country till the end of 2008 and the beginning of 2009 was indirect and comparatively soft. The main reason for that was our backwardness and our weak integration in the global financial system." (Sее АнгелоВ, ИВ., СВетоВната икономическа криза и България, Изgат. "М. Аринов", С., 2010, с. 177.)
} 


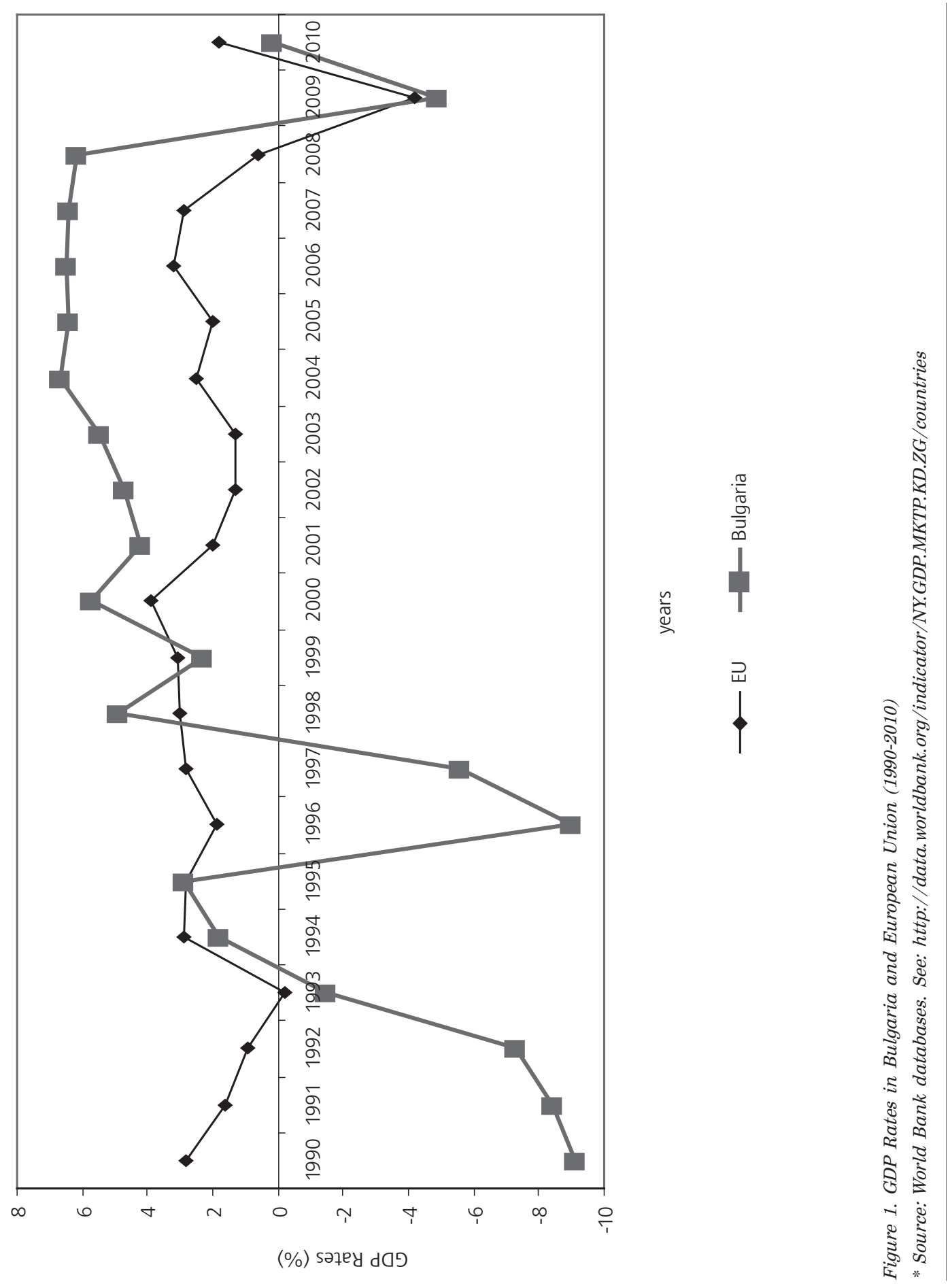


pressive impulses of transformational decline the transition economies can achieve an accelerated and long-term economic growth. Consequently, it increases the level of the total output, the inflationary pressure and the level of unemployment are reduced. There are created conditions for entering the final stage of the transformation process and for formation of a trend to a new trajectory of the economic development.

A comparison of dynamic characteristics of the Bulgarian economy and EU-27 shows that till the end of the 90s the trajectory of growth in the Bulgarian economy is quite different from that in European Union. European and world tendencies does not reflect on it, it is formed mainly under the influence of internal factors. Since the beginning of the $21^{\text {st }}$ century it has been under the growing impact of more profound participation of the country in the process of European integration. In the process of preparation of Bulgaria for realization of the EU membership and under the influence of a sustainable recovery of the national conditions of growth, after 2000-2001 the differentiations are limited, the form of macroeconomic dynamic in Bulgaria and EU become similar to a great extent. Bulgarian economy has developed at higher rates than those in European Union that reflect the acceleration impulses of transformational reforms and reorganizations. Even greater similarity to almost identity has been pointed to note about 2009 and 2010. It is the result of more closely interweaving of some national and regional factors and their gradual transformation into common internal (for European Union) factors of macroeconomic dynamics.

\section{External Determinants of the New Stage of Cyclical Development}

oreign relations and interactions, covering
mainly the import-export and foreign invest- ment flows (of foreign direct investments) determine the extent of openness of the national economy and they correlate closely with the macroeconomic dynamics.

Limited confines of the initial regional focus and the relative commercial isolation of Bulgaria are gradually overcome during the period of the market transition. Along with the market transformations Bulgarian economy has achieved a greater degree of trade and financial openness to European and world markets. In this respect are symptomatic the increasing number of countries foreign trade partners, the increasing in the valuable volume and the ratio to GDP of the export and import of goods and services as well as the foreign direct investments flows.

About the period 1991-2010 Bulgaria has enlarged almost twice the number of countries it keeps foreign trade relations and contacts from 117 countries in 1991 they rise to 200 in 2010 (and in some years their number is even up to 211). ${ }^{7}$ The openness follows a geographical direction from the east to the west distinguished during the changes that have come to geographical structure of export and import. The foreign trade exchange of goods has increased almost continuously (with some exceptions in the 90s and in 2009) and since 2005 its valuable volume has exceeded the level of GDP of the country. This ratio has been reversed in 2009 and 2010, when the foreign trade exchange of goods amounts to $82 \%$ and $96 \%$ of the volume of GDP. But it has remained within the range of over $80 \%$ accepted and implemented as a criterion for achieving a high degree of the foreign trade openness.

The degree of the economic openness can be also assessed on the basis of the expressed as a percentage ratio of the export and import to

\footnotetext{
7 Seе Cmamucmuчecku cnраßочнuk 1995 г., изg. на НСИ, с. 183; Cmamucmuчесku cnpaßочнuk 2011 г., с. 157.
} 
GDP of the country. ${ }^{8}$ Over the period 1991-2010, the valuable expression of the export to GDP in the country has varied in a wide range, amounting to $48 \%$ in 2010. For comparison among European countries the ratio export/ GDP is the highest in Slovenia (99\%), Ireland (89\%), Hungary (81\%), Belgium (73\%). ${ }^{9}$ On the other hand, for a number of the most highly developed countries of EU 15 this ratio is far lower - such as Spain (23\%), France (23\%), United Kingdom (28\%) and others. The ratio of the import to GDP of Bulgaria is slightly higher $-56 \%$ for 2010. By these two relative indicators Bulgaria is at the average positions in EU 27. Their implementation as benchmarks for openness also leads to a definite conclusion for unconditionally high degree of trade openness of the Bulgarian economy. ${ }^{10}$

Foreign investment interest in the country is characterized by low amounts and significant volatility of the foreign direct investments during the period covering the beginning of the market transition to the late 20th century (see Fig. 2.). They are intensified more tangible after the start of country's preparation for EU membership and its profound participation in the integration processes. Volumes of incoming for- eign direct investments have increased consistently and significantly since 2003. During the period 2001-2004, for example, in Bulgaria are implemented foreign direct investments of 6.3 billion dollars total that is twice more than the ones over all nine years of the market transformation from 1992 to 2000. The volume of foreign direct investments has reached its peak value in 2007 and has decreased sharply over the next three years in relation to the ongoing global financial and economic crisis.

The levels of the attracted foreign direct investments achieved in the country during the precrisis period and the relatively high percentage of their ratio to GDP (with a peak value of almost $22 \%$ in 2007) indicate the great degree of financial openness of the Bulgarian economy. Along with the high trade openness it increases the degree of dependence and sensitivity of the Bulgarian economy to the cyclical fluctuations in the economies of foreign Bulgarian partners.

Through the years of the market transformation it is implemented a cardinal geographical reorientation of the foreign trade flows that coincides with the key geographic sources of the inflows of foreign direct investments.

\footnotetext{
8 The three ratios presented here - the foreign trade circulation, the export and import to GDP of the country are the most often indexes used to be quantified the economic openness. Taking into account the increasing importance and volumes of the flows of exported and imported foreign direct investments that are another relatively new form of international economic relations there have been increasingly enriched the constructed more complex indicators of openness. For example, from the beginning of 21st century UNCTAD (United Nations Conference on Trade and Development) estimates the so-called Index of transnationalization of host economies. The index reflects the share of the foreign direct investments inflows in gross formation of the fixed capital, the ratio between the attracted foreign direct investments and GDP and many others. (Seе МариноB, В., ОтВореност и растеж на националната икономиka, Гоguuнuk на УHCC, C., 2006, с. 12-13.)

${ }_{9}$ According to the World Bank Databases. See: http://data.worldbank.org/indicator/NE.EXP.GNFS.ZS/.

10 It should be noted that the degree of openness is largely premised objectively. Sometimes it is an indirect sign of trouble at the domestic market resulting from the small volume of the market related to population, insufficient demand, low level of real incomes, limited in volume and variety available natural resources. It is known that in large countries with strong economic potential and strong growth as USA and Japan for example, the ratio of export to GDP varies around $10 \%$ but the weaker openness is not an obstacle to growth. In 2010 for example the ratios of export/GDP and import/GDP are respectively $11 \%$ and $14 \%$ about USA, $13 \%$ and $12 \%$ about Japan. The enormity of their domestic markets, having a good absorbability, allows the production to be realized smoothly. On the other hand, if absolute volumes of the total output and export are incomparably larger, the relative expressions are always small, and vice versa. Therefore behind the purely quantitative parameters must be sought the hidden diverse issues of growth and export that have outlined in direct and indirect effects of the export on macroeconomic processes and dynamics.
} 


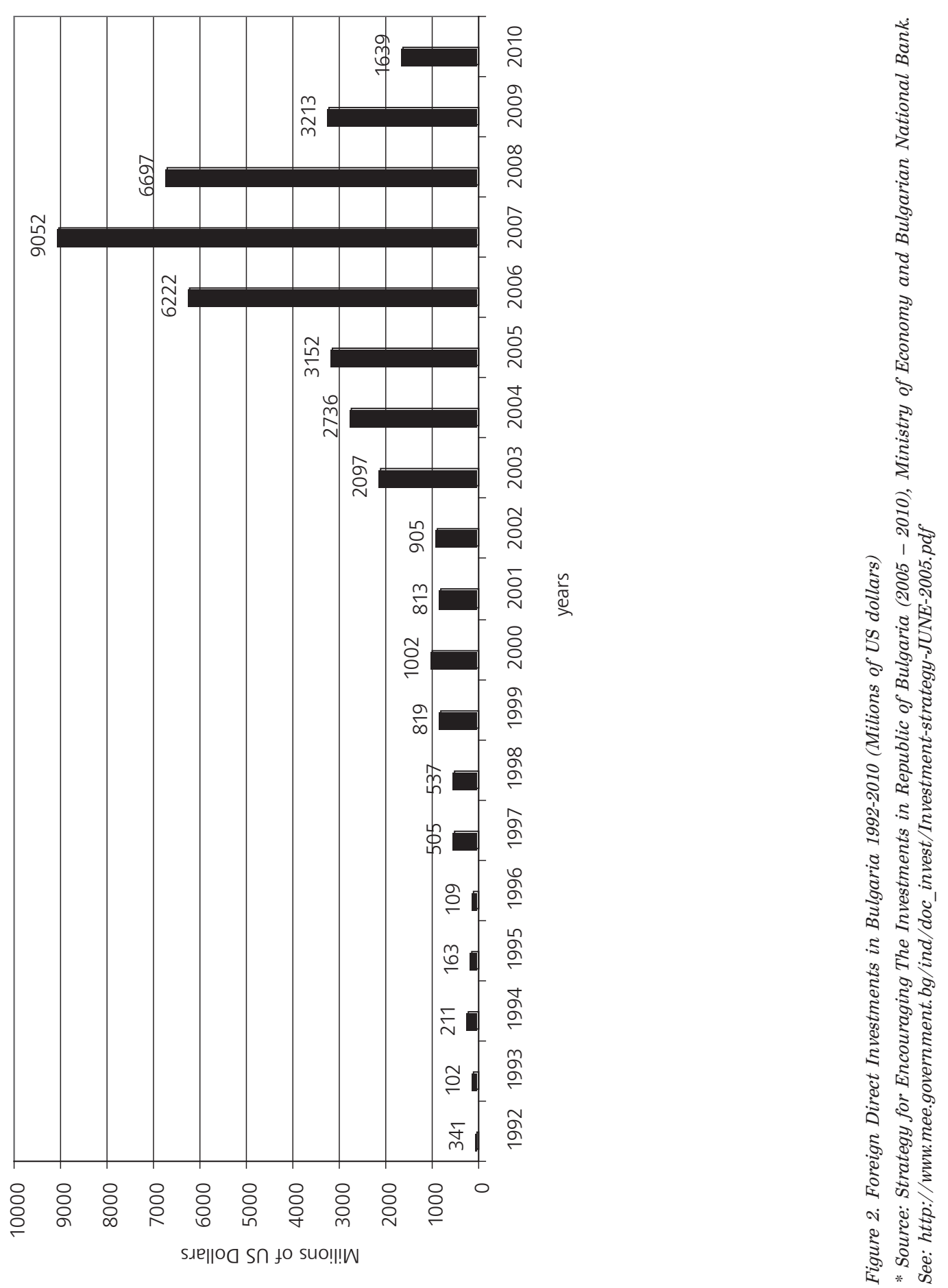


The place of the Central and Eastern European countries, whose total relative share in the export of Bulgaria for 1991 is the largest, amounting to $58 \%$, has no longer been dominant. In these countries, in the recent years and by 2010 Bulgaria has realized only about $20-21 \%$ of the export of goods and services. The export flows has been removed decisively to all EU countries which are targets of an average $60-61 \%$ of the value of export in the recent several years and in 2010. About the import there has also been a change in priority positions of the two groups of countries. The share of Central East-European countries in the import has declined from $48.5 \%$ in 1991 to $19-20 \%$, while the share of the EU countries as a whole has increased from $32.8 \%$ in 1991 to $58-59 \%$ by $2010 .{ }^{11}$ Raw-energy dependence of Bulgarian economy remains closely related to Russian suppliers, although the greatest place in the import (and export) has already the EU member states. At the end of the period their participation exceeds repeatedly the relative results of the commercial contacts between Bulgaria and Russia or some other countries.

In the geographical characteristics of the foreign direct investments inflows is established a similar concentration. A very large part (between $70 \%$ and $80 \%$ ) of the foreign direct investments realized in the country is from the EU member states. The largest share in the total amount of attracted foreign direct investments in Bulgaria in the recent years has belonged to Netherlands, Austria, Germany, United Kingdom, France, Belgium, Greece and many others.

The dynamics and geographical characteristics of the realizing foreign direct investments in the country allow to be derived two divergent conclusions. On the one hand, the growth in the volumes of foreign direct investments inflows increases the degree of dependence and the impact of the inherent for foreign direct investments greater cyclical volatility on the macroeconomic dynamics in Bulgaria. On the other hand, the channels of transmission of such influences and their power are limited because of the overwhelming importance of the relatively small number of EU countries that are a source of foreign direct investments in the country and are among the most highly developed and stable economies in the world.

From these data it can be concluded that in the increasing openness of the Bulgarian economy has not been avoided the dense concentration of import-export flows and foreign direct investments inflows in the relatively small number of countries (EU 27), it has still retained, although it was modified. Regrouping corresponds to the previous stage of preparation and to the realization of the country's accession to European economic structures in 2007 and parallel with that it has deepened the integration and trade relations and interactions between Bulgaria and the other EU countries. It prevents bringing the economic openness to a broader basis, but the new created model of country's foreign trade (and foreign capital flows) is more rational having in mind that the risk of the external cyclical impulses is reduced to some extent. Most important in this field in the recent years has been the increased stability and cyclical resistance of the unified EU economy as a result of the growing areas of commitment and the real integration of national economies of the EU 27 countries.

In terms of the market transition and transformational cycle in Bulgarian economy is complicated the interdependence between

11 Calculations of the relative shares are done by the author based on data from: Cmamucmuчecku cnpaBoчнuk 1995 2. u Cmamucmuчесkи cnраВочник 2011 г., разgели "Износ и Внос на сmoku". 
the real increases of the total output and the foreign trade. Over the period of the 90s have outlined some separate strains - during some of the years the dynamics and generalized parameters of import-export activity differ with the direction of economic growth or decline (see Table 2.). Over the only three years of a positive balance of the foreign trade (1991, 1996 and 1997) so far it has been reported a decline in the real GDP. During the years from 2000 to 2008 it is pointed to note simultaneously, but in varying degrees some increase in the value of export and imports, however, as a result of that it has remained the negative sign of country`s net export. Only over 2009 it has been recorded a parallel reduction of export and import related to the recession contraction of European and world markets as well as to the Bulgarian production.

Over the past decade the stabilized macroeconomic dynamics in Bulgaria has predisposed to expansion of the export and its total value increases intensively. Greater total output requires more raw materials and along with the rising incomes and purchasing power of the internal market it determines a substantial increase in the import of goods. Therefore, although both two sides and directions of foreign trade flows are operated, the trade deficit remains unsurmounted.

Table 2. Bulgarian Foreign Trade Indicators (1991-2010)*

\begin{tabular}{|c|c|c|c|c|c|}
\hline Period & $\begin{array}{c}\text { Export } \\
\text { (millions of BGN) }\end{array}$ & $\begin{array}{l}\text { Export Rates } \\
\text { (percentage) }\end{array}$ & $\begin{array}{c}\text { Import } \\
\text { (millions of BGN) }\end{array}$ & $\begin{array}{l}\text { Import Rates } \\
\text { (percentage) }\end{array}$ & $\begin{array}{c}\text { Foreign Trade Balance } \\
\text { (millions of BGN) }\end{array}$ \\
\hline 1991 & 58976 & & 53184 & & 5792 \\
\hline 1992 & 94630 & & 106325 & & -11695 \\
\hline 1993 & 114210 & -9.9 & 136976 & +18.4 & -22766 \\
\hline 1994 & 236770 & +9.8 & 240055 & -2.1 & -3285 \\
\hline 1995 & 393172 & -1.7 & 407204 & +2.3 & -14032 \\
\hline 1996 & 1099950 & -23.4 & 1045842 & -32.4 & 54108 \\
\hline 1997 & 10555860 & +3.1 & 9612221 & -2.6 & 943639 \\
\hline 1998 & 10552558 & -4.7 & 10500941 & +12.1 & -51617 \\
\hline 1999 & 10601 & -5.0 & 11974 & +9.3 & -1373 \\
\hline 2000 & 14902 & +16.6 & 16334 & +18.6 & -1432 \\
\hline 2001 & 16494 & +8.5 & 18712 & +13.0 & -2218 \\
\hline 2002 & 17180 & +7.0 & 19321 & +4.9 & -2141 \\
\hline 2003 & 18500 & +8.0 & 21779 & +15.3 & -3279 \\
\hline 2004 & 22210 & +13.1 & 26111 & +14.1 & -3901 \\
\hline 2005 & 25766 & +8.5 & 32692 & +13.1 & -6926 \\
\hline 2006 & 31861 & +8.7 & 41131 & +14.0 & -9270 \\
\hline 2007 & 35789 & +6.1 & 47656 & +9.6 & - 11867 \\
\hline 2008 & 40342 & +3.0 & 54558 & +4.2 & -14216 \\
\hline 2009 & 32458 & -11.2 & 38493 & -21.0 & -6035 \\
\hline 2010 & 40733 & +16.2 & 42074 & +4.5 & -1341 \\
\hline
\end{tabular}

* Sources: Main Macroeconomic Indicators, 1997, p. 113; Cmamucmuчecku cnpaвочник 2002-2011 2., uзg. на НСИ, разgели "Износ и внос на стоки". 
These conclusions do not concern the period when Bulgaria is affected by the spread and impact of the global financial and economic crisis of 2008-2009. It causes both the limit of growth rates of exports and imports of goods in 2008 and their absolute reduction in 2009 (see Table 2.). Parallel with that are significantly reduced the flows of incoming foreign investment into Bulgarian economy. These two parallel trends refute the applicability in a crisis of the theoretical concept of B. Olin about that "the commodity trade and capital migration are alternative forms of international economic relations - the expansion of one of them leads to a shortening of the other."12

The formation of a positive trade balance (during the years of the ascending phase of the transformational cycle and by the transition to the regularities of the cyclical development) is hampered by mainly represented industrial and commodity positions of the export and import sectors of Bulgaria. In the export the most widely used is the production of low and middle technological sectors of the mining and manufacturing industry. In the recent years the largest relative share in sales at the foreign markets has been kept by the production of shoes industry, the textiles and garments production, the furniture and corn production. In country's export there have almost not been the products of electronics and electrical engineering, occupying a large share in the assortment composition and its value so far. Higher technological or more expensive products such as industrial machinery and equipment, household technics and raw materials are mainly an object of import. If there are such characteristics of the foreign trade flows the national production is more expensive and discouraged, "the economy is adjusted to permanent dependence on the import of goods and services and could not develop its internal economic potential."13
Meanwhile it has been formed a wide opened channel for transfer on Bulgarian economy of the recessionary growth disturbances occurring in some other countries and the turmoils of the international markets.

The main characteristics of the sectors structure of GDP and the export of goods from Bulgaria are played to large extent in the industrial focus of foreign direct investments. Before the beginning of the crisis of 2008 the largest share (over $60 \%$ ) of the foreign direct investments has been realized in the sectors of services, while the industry sector has been less preferred. The largest inflow of foreign direct investments over those years has been recorded in the financial sector, real estates and trade, where are implemented over two thirds of the total foreign direct investments inflows in the country. The efficiency of incorporation of foreign investments is not particularly high because of the low volume of foreign direct investments in the industry sector as also because of the mainly distribution of their assets in sectors and industries with created low added value.

The increased investments risk in these sectors under the impact of global crisis, has redirected the incoming foreign direct investments flows in 2010 to the industry and in particular to the sectors of manufacturing industry. By a share of $36 \%$ the manufacturing industries have occupied the leading place in the industrial focus of the foreign direct investments in the country.

It may be concluded that the foreign investments are attracted to the most intensively developing branches and recently have showed a tendency of reorientation from the sources of quick profits to more stable and long-term more reliable areas for investments. In this respect the potential of

\footnotetext{
12 Seе МариноВ В., Теоретични концепции за преkume Външни инВестиции, Научни mpуgоВе на УНСС, m. 2, 2008 , с. 7. 13 See Aokıаg за Презиgента на Република Бьлгария 2009, СВетоВната финансоВо-икономическа kриза и България, С., 2009, c. 43, http://www.president.bg/pdf/Doklad2009.pdf
} 
foreign direct investments for transfer of cyclical impulses weakens and it is replaced by a more realistic opportunity to accelerate the economic growth in Bulgaria. That kind of their influence, however, has still remained limited so far because of the unconvincing performance of the foreign direct investments in prospective areas associated with developing and implementing of the new technologies, production of high-tech, competitive and export oriented production.

In the foreign trade flows and foreign direct investments are established a number of positive trends concerning the formation of a larger cyclic resistance of the dynamics of Bulgarian economy. Overcoming the crisis tension, restoring the macroeconomic stability, the expansion and profundity of integration relations and synergies with the other EU countries are essential preconditions for the intensification and acceleration of the economic growth in the next years.

\section{References}

1. АнгелоВ, ИВ., СВеmоВната икономическа kриза и България, Изgат. „М. АриноВ”, С., 2010.

2. Гринин, ^., А. KopomaeB, Г^обальный kрuзис B pempocnekmuße. Краmkая uстория nоgьемоB и kризисов, uзgат. „Книжный gом АИБРОКОМ", М., 2009.

3. Aokıag за Презиgенmа на Реnублика България 2009, СВемоßната финансоßо- ukономическа криза и България, С., 2009, http://www.president.bg/pdf/Doklad2009.pdf

4. EBpocmam, http://epp.eurostat.ec.europa.eu

5. МариноВ, В., ОmВореност и растеж на националната икономика, Гоguшник на УНСC, C., 2006.

6. МариноВ, В., Теоретични концепции за nрекumе Външни инВестиции, Научни mpygоВе на УНСC, m. 2, 2008.

7. СВемоВна банkа, http://www.worldbank.org

8. CnacoB, Тр., Пазарна трансформация и kонкурентоспособност на ukономикume B npexog, УИ "CmonaнсmBо", С., 2006.

9. CmameB, Cm., Реалната ukономика и банkоßата система на България: емпиричен анализ 1991-2006 г., Научни mpygоВе на УНСС, м. 2, 2009.

10. Cmamucmuчecku cnpaßoчнuk, 1995-2011, uзg. на НСИ.

11. СтефаноВ, Аим., Българсkият моgел на npexoga, B: Проблеми на ukономикume B nреxоg, uзgam. „Параguгма", С., 2000.

12. Cmpamezия за насьрчаВане на инВестиuuume B Penyблиkа България (2005-2010 г.), MuнuстерстВо на ukономukama, http:// www.mee.government.bg/ind/doc_invest/ Investment-strategy-JUNE-2005.pdf $\overline{\mathrm{E} A}$ 